Article

\title{
Spatial Distribution of the Baltic Sea Near-Shore Wave Power Potential along the Coast of Klaipèda, Lithuania
}

\author{
Egidijus Kasiulis ${ }^{1, *}$, Jens Peter Kofoed ${ }^{2}$ (D), Arvydas Povilaitis ${ }^{1}$ and Algirdas Radzevičius ${ }^{3}$ \\ 1 Institute of Water Resources Engineering, Aleksandras Stulginskis University, Universiteto 10, Akademija, \\ LT-53361 Kaunas distr., Lithuania; arvydas.povilaitis@asu.lt \\ 2 Department of Civil Engineering, Aalborg University, Thomas Manns Vej 23, Aalborg 9220, Denmark; \\ jpk@civil.aau.dk \\ 3 Institute of Hydraulic Engineering, Aleksandras Stulginskis University, Universiteto 10, Akademija, \\ LT-53361 Kaunas distr., Lithuania; algirdas.radzevicius@asu.lt \\ * Correspondence: egidijus.kasiulis@asu.lt; Tel.: +370-621-83902
}

Received: 6 November 2017; Accepted: 18 December 2017; Published: 19 December 2017

\begin{abstract}
Wave power is an abundant source of energy that can be utilized to produce electricity. Therefore, assessments of wave power resources are being carried out worldwide. An overview of the recent assessments is presented in this paper, revealing the global distribution of these resources. Additionally, a study, which aims to assess the spatial distribution of the Baltic Sea near-shore wave power potential along the coast of Klaipeda (Lithuania), is introduced in this paper. The impacts of the wave propagation direction and decreasing depth on wave power resources were examined using the numerical wind-wave model MIKE 21 NSW. The wave height loss of the design waves propagating to shore was modelled, and the wave power fluxes in the studied depths were calculated using the JONSWAP wave spectrum modified for the Baltic Sea. The results revealed that all waves that propagate to the shore in the Baltic Sea near-shore area along the coast of Klaipeda from $30 \mathrm{~m}$ depth to $5 \mathrm{~m}$ depth lose at least $30 \%$ of their power. Still, most common waves in this area are low, and therefore, they start to lose their power while propagating to the shore at relatively low (10-14 $\mathrm{m})$ depths. To turn this into an advantage the wave power converter would have to work efficiently under low power conditions.
\end{abstract}

Keywords: near-shore wave power; spatial distribution; propagation direction impact; depth impact; Baltic Sea

\section{Introduction}

It is globally recognized that wave power has great potential to be a future source of electricity. More important is that this is a renewable and abundant resource. The attractiveness of wave power potential is reflected in the growth of the Ocean Energy Systems (IEA-OES) organization. This organization was founded in 2001 by Portugal, Denmark and UK representatives. By 2013, when Nigeria and Monaco joined IEA-OES, the organization had 21 state members [1]. The increasing attention that the power of waves has attracted in the last century has resulted in a vast number of scientific studies. A fair amount of these studies are dedicated to the assessments of wave power potentials.

Global wave power resources are usually presented as within the interval from 1 to 10 TW [2]. These values are quoted so frequently that it is difficult to trace the original source. Kinsman, the author of these values, has warned about the potential errors in his calculations [3]. The latest attempts to revise the value of global theoretical wave power resources were published in 2010 and 2012, and the 
estimated values were 3.7 TW and 2.1 TW, respectively [4,5]. Possible annual electricity generation from waves could be up to 18,500 TWh [6]. The identification of the spatial distribution of global wave power resources is attempted in the introduction of this paper with an overview of the latest related scientific studies.

\subsection{Americas}

In North America, both Canada and the USA are promoting wave power research projects mainly because both countries are situated between latitudes $30^{\circ}$ and $60^{\circ}$ in the northern hemisphere, where it is known that the highest density of wave power resources is situated. On the other hand, the trust in renewable energy technologies also helps. The assessment of wave energy resources in Oregon and southwest Washington, USA was completed just in time to assist the attainment of the goal that by 2025 two coastal communities in the state of Oregon will be powered completely by ocean energy [7]. In this study, the common methodology of using a large scale numerical model with lower resolution to simulate offshore sea conditions was adopted. In this case, it was the WaveWatch III model [8], while the more detailed near-shore conditions were modelled with Simulating WAves Nearshore (SWAN). It was found that the average annual wave power resources at the $50 \mathrm{~m}$ isobath are $25 \mathrm{~kW} / \mathrm{m}$ [7].

Garcia-Medina and his colleagues' study [7] is in an agreement with an earlier published study [8] concerning the same region's wave energy resource. Both studies propose the use of a wider range of wave parameters for wave energy resource assessments. In addition to significant wave height and energy periods, which are widely used for scatter diagrams, they included parameters such as spectral width, direction of the maximum directionally resolved wave power, and directionality coefficient and calculated omnidirectional wave power [7,9]. However, use of this wider range of wave parameters is only possible when the data consists of not only spectral density but also its distribution over directions.

Lenee-Bluhum and his colleagues [9] use only buoy measurement data for their wave power characterization. The analysis of this type of data allows for the determination of daily variations of wave power and the more thorough assessment of resources. The drawbacks are that the network of buoys is not dense enough everywhere and that the length of their measurements is not always long enough to carry out an appropriate spatio-temporal wave power distribution analysis. A newly proposed standard for wave energy resource assessment and characterization envisages a minimum of 10 years of data for these types of studies [10]. Thus, it is not surprising that, except for the buoy measurements, a huge amount of effort is focused on developing wave forecasting models such as WAve Model (WAM), which is used at the European Centre for Medium-Rage Weather Forecasts (ECMWF) [11].

Canadian scientists state that the capital costs of the wave energy converters are already low, and therefore, they are attempting to select the best location for these converters in the Canadian territorial sea waters [12]. One hundred forty-two stations comprised of wave records for longer than one year from over 300 locations were assessed. Three wave energy converters were used in the study (AquaBuOY, Pelamis and WaveDragon). It was determined that WaveDragon is the most suitable wave energy converter for both Atlantic Ocean and Pacific Ocean locations with an average capacity factor of $25 \%$ [12].

Caribbean Sea wave power resources were assessed in Colombia [13]. It is not a coincidence that much of the attention in this study was paid to the numerical model setup because the main issue here is the scarcity of the instrumental wave measurements. Near-shore wave energy resources in this case were assessed with the help of the SWAN model. The estimated average wave power flux is not high $-1 \mathrm{~kW} / \mathrm{m}$-but the authors state that the wave energy in the Caribbean Sea can be used to generate electricity, especially in the islands where the supply of energy is expensive [13]. Similarly, there is expensive to supply fuel for generators that power offshore oil rigs in the Gulf of 
Mexico. Therefore, there is suggestion to supplement needed energy with electricity generated from the waves [14].

Uruguay and Brazil are two other countries in South America where attempts to assess the wave energy potential have been made. Studies were carried out in territories within close proximity to each other-the Rio la Plata and Uruguayan waters in the Atlantic Ocean [15] and the coast of the state of Santa Catarina in Brazil [16]. Although different wave models were selected (WaveWatch III and MIKE 21 SW) for the near-shore wave energy assessment, the authors of both papers remarkably elected to analyse wave energy resources at $20 \mathrm{~m}$ depth. The results obtained were very similar: along the Uruguayan coast, the wave power flux ranges from 8 to $14 \mathrm{~kW} / \mathrm{m}$, while along the Brazilian coast, the flux ranges from 8 to $14.5 \mathrm{~kW} / \mathrm{m}$. Both studies highlight the low seasonal variability of the wave energy, which is what makes these coasts particularly attractive for electricity production from waves $[15,16]$.

\subsection{Asia}

There are plenty of recently published studies concerning wave energy resource assessments in Asia. Firstly, we concentrate on the eastern part of the Mediterranean Sea. Here, Lebanon has joined a not inconsiderable number of European countries that are interested in electricity production from Mediterranean Sea waves. Although the average wave height along the coast of Beirut is $78.1 \mathrm{~cm}$, the noted average annual wave power flux is $4.6 \mathrm{~kW} / \mathrm{m}$ [17]. Interestingly, the authors of this study are trying to evaluate the performance of Pelamis, WaveDragon and AquaBuoy wave energy converters (WECs) in these conditions. Unsurprisingly, the capacity factor for these converters on the eastern coast of the Mediterranean Sea is $4-6 \%$, and the authors come to conclusion that these WECs are not optimum solutions in these waters [17]. On the other hand, the scarcity of wave energy converter power matrixes is limiting the options for scientists in this type of study. Therefore, scientists in Iran, whose goal was to select the most suitable wave energy conversion technology for the Caspian Sea, chose a different approach. With knowledge of the wave power flux range in the Caspian Sea (5 to $14 \mathrm{~kW} / \mathrm{m}$ ) and specific features of the Caspian Sea (salinity, water level fluctuations, near-shore seabed composition, etc.), they selected the most suitable of over 20 state of the art WECs by assigning weights according to each WEC design parameter [18]. Of course, this rating of WECs is quite subjective, but it is a methodically suitable solution.

Wave energy resources were assessed in detail for northern Iran, the southwestern region of the Caspian Sea [19]. The study area was near the port of Anzali, and bathymetry data up to $700 \mathrm{~m}$ was used. With the help of SWAN for the wave climate model, it was found that an average annual wave power varies from $0.2 \mathrm{~kW} / \mathrm{m}$ to $1.2 \mathrm{~kW} / \mathrm{m}$. Also, there is quite a high seasonal variation of the wave power in this region: wave power in winter may be up to 2.5 times higher than in summer [19]. The findings of this study also imply that the authors of the previous reference may have overestimated the power potential of the Caspian Sea waves.

The interest in wave power in Iran does not end in the Caspian Sea: the wave power potential of the Persian Gulf was also analysed [20]. Again, with the help of the SWAN model, not only the wave power potential but also the influence of the prevailing wind direction on the wave power in this shallow gulf (average depth $36 \mathrm{~m}$ ) was examined. The findings were remarkable: a $6 \%$ change of the wind direction in this case can result in a 77\% decrease of the wave power. The estimated average wave power in the Persian Gulf is not high: in the deepest areas, it reaches $2 \mathrm{~kW} / \mathrm{m}$ [20].

Attention to wave energy is growing in China. This is proved by the number of recent original research $[21,22]$ and review $[23,24]$ papers. Unfortunately, the highest average value of the wave power flux along the Chinese shore in the northern part of the South China Sea is only $16 \mathrm{~kW} / \mathrm{m}$ [21]. The near-shore numerical model of the Shandong peninsula's coasts revealed that the average wave power flux of the Yellow Sea is only $5.1 \mathrm{~kW} / \mathrm{m}$ [22]. Wave power flux values are similar for the South Korea coasts, and although it is noted that in the winter the wave power flux here can reach 
$25 \mathrm{~kW} / \mathrm{m}$ [25], this value is more important for the wave energy converter load estimations than for actual electricity generation.

On the other hand, the peculiarity of the southeast Asian climate should not be forgotten. The winter monsoon season is noted not only by Korean scientists but also by Malaysian [26] and Taiwanese [27] scientists. It was estimated that up to $84 \%$ of the total wave power is generated during the winter monsoon season in Taiwan [27]. The temporal distribution assessment of the wave energy resource in the Indian shelf seas was even performed by dividing the year into pre-monsoon, south-west monsoon and post-monsoon periods [28]. Because wave power fluxes can exceed $100 \mathrm{~kW} / \mathrm{m}$ during typhoons, the regular typhoons in Southeast Asia also should be taken into consideration. Additionally, adjustments to WEC designs should be made [27].

\subsection{Australia and New Zealand}

While the northern coasts of Australia are described as unsuitable places for electricity generation from waves because of their relatively low resources [29], the southern coasts can only be described as unique. Extremely long fetches provide the conditions for the highest wind waves in the world, and the length of this coast is $3000 \mathrm{~km}$ [30]. With wave power fluxes reaching $30-50 \mathrm{~kW} / \mathrm{m}$, it is estimated that wave energy resources in Australia's southern coasts represent five times the energy requirements of the whole of Australia [31]. Therefore, it is not surprising that the capacity factor for the same WECs assessed for their suitability to the east Mediterranean Sea's Lebanon coast exceeds $50 \%$. Moreover, it is estimated that the cost of electricity produced from a wave energy converter situated $5 \mathrm{~km}$ from shore can be comparable to electricity generated from wind or sun power plants [31]. Although New Zealand can appreciate similar wave power to that of the southern Australia coast, recent developments show that in this country there is no requirement for detailed wave energy assessments. New Zealand is applying a cautious approach to wave energy $[1,32]$.

\subsection{Africa}

Two African countries are members of the IEA-OES: South Africa and Nigeria. An assessment of the wave energy resources in South Africa revealed that it has extensive wave energy resources, especially in the southwestern coast, where in offshore locations wave power fluxes vary from $33 \mathrm{~kW} / \mathrm{m}$ to $41 \mathrm{~kW} / \mathrm{m}$. The near-shore average annual wave power flux is $26 \mathrm{~kW} / \mathrm{m}$ [33]. So far there is no information about such assessments in Nigeria [34].

An assessment of ocean renewable resources in the western Indian Ocean was published in 2012. Wave energy was discussed, along with tidal, ocean current and ocean thermal energy. The assessment was carried out for the coasts of Kenya, Tanzania and Mozambique; and the islands of Madagascar, Reunion and Mauritius [35]. It is worth mentioning that this region has one of the lowest electrification rates in the world: the rates in Kenya, Tanzania, Mozambique and Madagascar are less than 20\% [36]. The average offshore wave power flux value here of $25 \mathrm{~kW} / \mathrm{m}$, and the future perspective is that wave power in this region can be used not only for electricity generation but also for desalination of sea water. Unfortunately, the strong tropical cyclones in this area will be a serious limiting factor for WECs installations [35].

\subsection{Europe}

Europe's wave energy resources were recently reviewed in reference [37], which focused more on the European semi-enclosed seas. A browse through the latest published studies reveals two main directions of research concerning wave energy potential in Europe. The first one is the North Atlantic coasts, where Europe has its highest wave energy potential. Here, an international scientific collaboration (the EnergyMare project) to create a map of wave energy resources along the European Atlantic coast was established [38]. In the project, the results of WaveWatch III and SWAN models were compared, and wave energy resources in potential wave energy conversion or test sites in Scotland, France, Spain and Portugal were evaluated. According to the results, the four above mentioned 
countries in descending order of their wave energy resources are Scotland (up to $40 \mathrm{~kW} / \mathrm{m}$ in Shetlands), France (up to $34 \mathrm{~kW} / \mathrm{m}$ in Bretagne), Spain (up to $34 \mathrm{~kW} / \mathrm{m}$ in Estaca de Bares) and Portugal (up to $24 \mathrm{~kW} / \mathrm{m}$ in Nazaré) [38]. Furthermore, the attractiveness of this region for electricity generation from sea waves is reflected in recently published wave energy resource assessments for Ría de Vigo (Spain) [39], the Iberian Peninsula [40], the Sea of Iroise (France) [41], Galway Bay (Ireland) [42] and Ireland [43]. The last study not only focuses on wind and wave energy potential in Ireland but also evaluates the correlation between these two renewable power sources. This is important because synergy is possible when converting wind and wave energy into electricity via purposely designed wave power plants such as Wavestar [44].

The second main direction of the wave energy potential studies in Europe is the Mediterranean Sea. New studies are constantly being conducted to update knowledge of the whole Mediterranean Sea's wave energy potential via high resolution models [45]. Additionally, high resolution models are used for the regional assessment of wave energy, e.g., the Greek offshore areas [46]. A study concerning wave energy resources in the Balearic Sea revealed new "hot spots" in the Mediterranean Sea that are viable for WEC construction-the northern coast of Spain's Menorca Island and the northern, western, and eastern coasts of Spain's Mallorca Island [47].

"Hot spot" is usually understood as an area with the highest concentrated wave power potential, but in the Mediterranean Sea this perception is beginning to change. Because the seasonal variation of wave energy is very high here-in winter, the wave power flux can be up to 5-6 times that of the summer [47] - the actual "hot spot" for WEC in the Mediterranean Sea can be an area with the lowest coefficient of variation, which means a more consistent value of wave energy throughout the year [45]. For this reason the studies of the lower wave energy potential regions-areas such as the Aegean Sea, where the average wave power flux is $2-2.5 \mathrm{~kW} / \mathrm{m}$ [48]—can become more and more important in the future.

\subsection{Islands}

Islands in this overview are presented separately because they are the areas where the supply of energy is usually a very important and expensive issue. For example, in St. George Island (USA), located in the Bering Sea approximately $500 \mathrm{~km}$ from the Alaskan shores, energy is generated via four diesel generators. It has been evaluated that a WEC situated $3 \mathrm{~km}$ from the shore at $40 \mathrm{~m}$ depth, where the average wave power flux is $28 \mathrm{~kW} / \mathrm{m}$, would save the local community fuel costing approximately US $\$ 81,600$ annually [49]. There could be considerable support from the islanders (population 100), whose main economic activity is fishing.

Another island of the USA, whose remoteness is the reason for the pursuit of alternative energy sources, is Hawaii. Here, the average wave power flux at $60 \mathrm{~m}$ depth varies from $15 \mathrm{~kW} / \mathrm{m}$ to $30 \mathrm{~kW} / \mathrm{m}$. The newly established Hawaii National Marine Renewable Energy Center has already selected an area designated for a wave energy test site [50].

The Azores Islands (Portugal) was one of the first areas where the renewed attention to the marine energy in Europe has materialized. Here, on Pico Island in 1999, an oscillating water column type WEC was built [51]. Unfortunately, a lack of funding slowed down the development process in this case, although the wave energy resources in the Azores Islands are twice as large as in Hawaii [52].

The Canary Islands (Spain) are another area in the Northern Atlantic suitable for wave energy conversion. The average wave power flux here is similar to Hawaii at $25-30 \mathrm{~kW} / \mathrm{m}$ [53]. The assessments of the wave energy resources for these islands continue constantly [54]. Additionally, the study of the effect of WECs on the incoming waves in the near-shore area of Tenerife was carried out in reference [55]. Although the purpose of this study was different, the related idea to use WECs as a shore protection measure is becoming quite common [56].

A European island with one of the highest wave energy potentials is Iceland. The average wave energy flux on Iceland's coast at the $50 \mathrm{~m}$ depth can reach $45 \mathrm{~kW} / \mathrm{m}$ [57]. On the other hand, the severe 
climate conditions and the fact that Iceland already generates all of its electricity from renewable sources [58] raises doubt on whether Iceland will press ahead to realize the potential of wave energy.

Another group of islands with impressive wave energy resources is Fiji. The estimated wave energy potential of Fiji is $29 \mathrm{GW}$. If the country could realize $0.5 \%$ of this potential, it would still be sufficient to meet its electricity demand [56].

Tapping the wave energy potential will be important not only for the islands that are situated in the open ocean. In the Mediterranean Sea, the area with the highest wave energy is the western coast of Sardinia [59]. Recently, a hot spot was discovered in Sicily's near-shore area [60]. In the Baltic Sea the possibility to generate electricity from the waves was studied in the area close to the island of Aland [61].

The worldwide wave energy assessments are summarized in Table 1, where the coastal wave power fluxes are presented in ascending order. Efforts were made to select and present in the table only those wave power flux values that were presented as averaged in the different studies. Table 1 clearly shows that wave energy resources are distributed unevenly around the world and that these resources are highest in the coasts that have the longest fetches.

Table 1. The distribution of wave energy resources worldwide.

\begin{tabular}{cccc}
\hline Wave Power Flux, $\mathbf{k W} / \mathbf{m}$ & Country, Region & Sea, Ocean & \multicolumn{2}{c}{ Reference } \\
\hline 1 & Colombia & Caribbean Sea & {$[13]$} \\
1.1 & Turkey & Black Sea & {$[62]$} \\
2 & Iran & Persian Gulf & {$[20]$} \\
4.6 & Lebanon & Mediterranean Sea & {$[17]$} \\
5.1 & Shandong Peninsula (China) & Yellow Sea & {$[22]$} \\
$5-14$ & Iran & Caspian Sea & {$[18]$} \\
$15-30$ & Hawaii & Pacific Ocean & {$[51]$} \\
$20-40$ & Norway & Atlantic Ocean & {$[63]$} \\
25 & Pacific Ocean & {$[7]$} \\
25 & States of Oregon and Washington (USA) & Indian Ocean & {$[35]$} \\
$25-30$ & Southeast Africa & Atlantic Ocean & {$[54]$} \\
30 & Canary Islands & Atlantic Ocean & {$[64]$} \\
$30-50$ & Bay of Biscay & Indian Ocean & {$[31]$} \\
\hline
\end{tabular}

\subsection{Lithuania}

The theoretical wave power resource of the Baltic Sea (excluding areas where the wave power flux is lower than $5 \mathrm{~kW} / \mathrm{m}$ and potentially ice-covered regions) is estimated to be $1 \mathrm{GW}$ [4]. Interestingly, the resource is confined to the southeastern region of the Baltic Sea, where the Lithuanian coast is located (Figure 1a). Swedish scientists estimated that the average wave power flux in the whole Baltic Sea can reach $4-5 \mathrm{~kW} / \mathrm{m}$ [65], whereas at the near-shore area along the Lithuanian coast, the multi-year average wave power potential reaches $1-2 \mathrm{~kW} / \mathrm{m}[37,66]$. The assessment of the temporal distribution of the Baltic Sea near-shore wave power resources along the Lithuanian coast was published in reference [37]. The spatial distribution of the Baltic Sea near-shore wave power resources along the coast of Klaipeda (Lithuania), presented in this paper, which is continuation of the work that was published in reference [37], was assessed for the first time. The impacts of wave propagation direction and decreasing depth on wave power resources in the area of low wave power potential were examined. This upgraded knowledge on the Baltic Sea near-shore wave power resources is also used in this paper to show where the Baltic Sea stands according to the wave power potential with reference to presented global distribution of these resources. 
b)

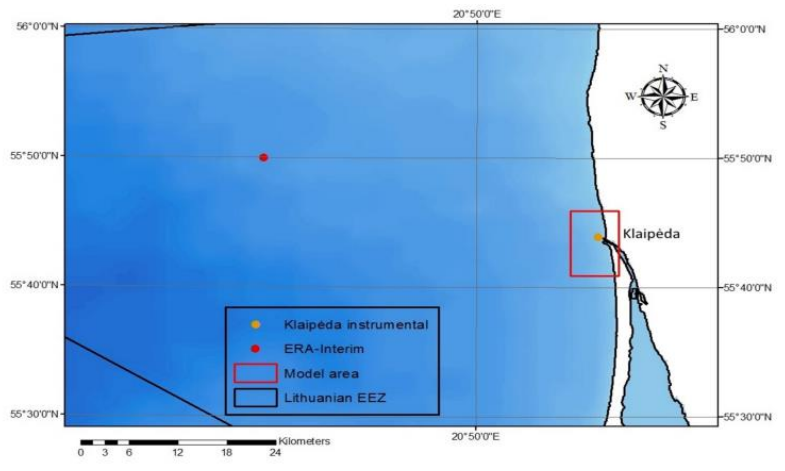

a)

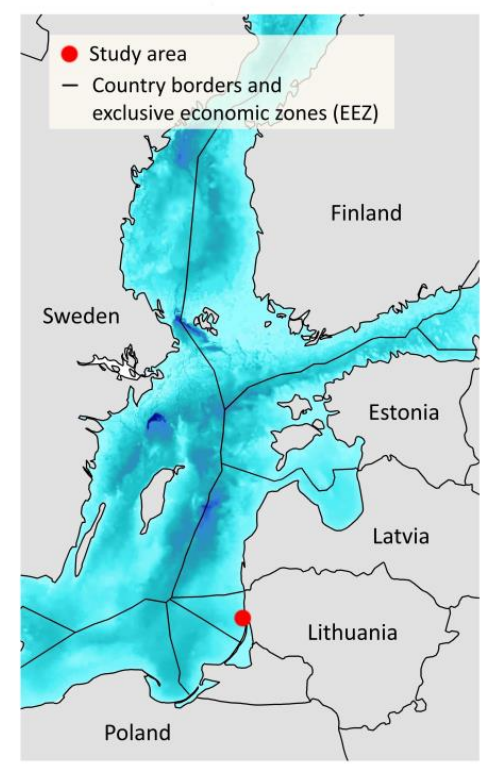

c)
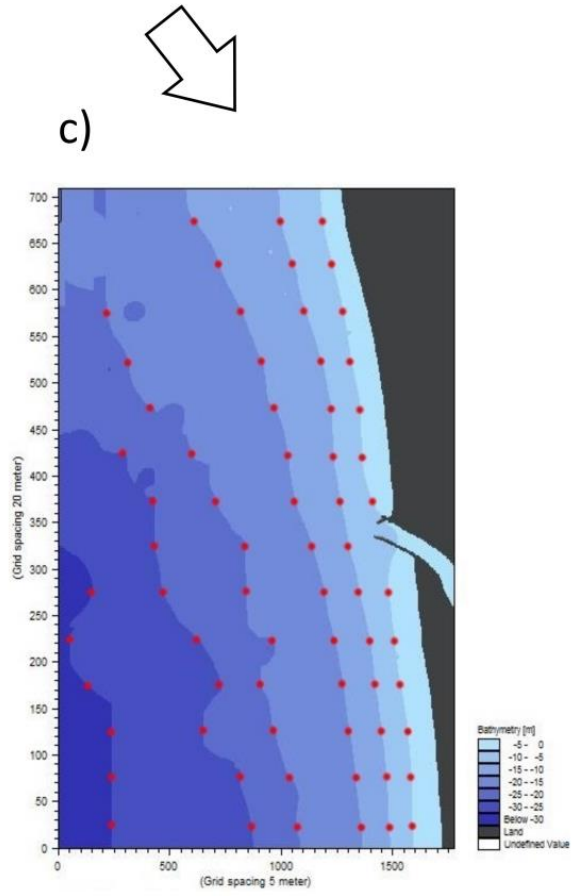

Figure 1. (a) Location of the study area in the southeastern part of the Baltic Seal; (b) model area together with the available wave data points used for model calibration; (c) bathymetry of the model area and calculation points.

\section{Materials and Methods}

\subsection{Numerical Model}

The MIKE 21 Nearshore Spectral Wind-Wave (NSW) model [67] was used to model the dynamics of wave height loss. The results were consequently the initial data used to assess the decreasing amount of the energy of waves propagating to shore. MIKE 21 NSW is a stationary, directionally decoupled parametric model that takes into account the effects of refraction and shoaling due to varying depth, local wind generation and energy dissipation from bottom friction and wave breaking.

The main equation of MIKE 21 NSW is the conservation equation for the spectral wave action density, which is solved via parameterization of the conservation equation in the frequency domain and the use of the zeroth and the first moments of the action spectrum as dependent variables.

The wave energy dissipation due to decreasing depth is controlled in the MIKE 21 NSW via bottom friction, the process by which the wave loses some of its energy due to the effect of friction at the sea bottom. The model's equation for the energy dissipation due to the bottom friction is based on the quadratic friction law [68]: 


$$
\frac{d E}{d t}=-\frac{1}{8 \sqrt{\pi}} \frac{C_{f w}}{g}\left(\frac{\omega H_{r m s}}{\sinh (k h)}\right)^{3}
$$

where $E=\left(H_{r m s}\right)^{2} / 8, \omega$ is the frequency, $H_{r m s}$ is the root mean square wave height, $k$ is the wave number, $h$ is the water depth, and $C_{f w}$ is the wave friction factor. The wave friction factor $\left(C_{f w}=f_{w} / 2\right)$ is specified by the Nikuradse roughness parameter [69]:

$$
f_{w}=\exp \left(-5.977+5.213\left(a_{b} / k_{N}\right)^{-0.194}\right), \text { when } a_{b} / k_{N} \geq 2,
$$

$k_{N}$ is the Nikuradse roughness parameter, and $a_{b}$ is amplitude of the particle motion at the bottom. The Nikuradse roughness parameter can be estimated by [70]:

$$
k_{N}=2.5 \cdot d_{50}
$$

where $d_{50}$ is the median grain size of the sediment. In the presence of ripples, the Nikuradse roughness parameter increases, and its estimate should include the ripple characteristics. Its value increases further if there is vegetation. It is difficult to assess this parameter, and therefore, it is used for model calibration.

The process of wave breaking due to large wave steepness and limiting depth in MIKE 21 NSW is based on the formulation for energy dissipation rate due to wave breaking [71]:

$$
\frac{d E}{d t}=-\frac{\alpha}{8 \pi} \cdot Q_{b} \cdot \omega \cdot H_{m}^{2}
$$

where:

$$
\frac{1-Q_{b}}{l_{n}\left(Q_{b}\right)}=-\left(\frac{H_{r m s}}{H_{m}}\right)^{2},
$$

where $E$ is the total energy, $\omega$ is the frequency, $H_{r m s}$ is the root mean square wave height, $H_{m}$ is the maximum allowable wave height, $Q_{b}$ is the fraction of breaking waves, and $\alpha$ is an adjustable constant. The maximum wave height is estimated by [71]:

$$
H_{m}=\gamma_{1} \cdot k^{-1} \cdot \tanh \left(\gamma_{2} \cdot k h / \gamma_{1}\right),
$$

where $\gamma_{1}$ and $\gamma_{2}$ are wave breaking parameters: $\gamma_{1}$ controls the steepness condition, and $\gamma_{2}$ controls the limiting water depth condition. In this case, $\alpha, \gamma_{1}$ and $\gamma_{2}$ are specified as constants for the whole model area, and they have values of 1.0, 0.8 and 1.0, respectively.

The location of the model area is presented in Figure 1b. This location was selected for its several advantages. Firstly, there is the possibility of using the test data of the bottom mounted wave recorder Aanderaa SeaGuard [72], operated by the Lithuanian Environmental Protection Agency's Department of Marine Research. Secondly, the Klaipeda Seaport breakwaters could be a suitable site for the installation of a wave energy converter in Lithuania.

\subsection{Model Calibration}

The model calibration was performed using instrumental measurements of the wave heights at $10 \mathrm{~m}$ depth $\left(55^{\circ} 43^{\prime} 55^{\prime \prime} \mathrm{N}, 21^{\circ} 4^{\prime} 20^{\prime \prime} \mathrm{E}\right)$, i.e., the test data of the bottom mounted wave recorder and the ECMWF ERA-Interim reanalysis data [73] from $50 \mathrm{~m}$ depth $\left(55^{\circ} 50^{\prime} \mathrm{N}, 20^{\circ} 25^{\prime} \mathrm{E}\right.$; Figure 1b). Term reanalysis means that ECMWF forecast is assimilated with measurements. In such way updated results are kept as ERA-Interim data-a reliable information on atmosphere, land and oceans.

The model was run in quasi-stationary mode with the additional supplementation of the time series of the model coastal areas' wind speed and direction for the simulation period. ERA-Interim data were used as offshore wave height boundary conditions for the higher resolution near-shore model. 
Of all the parameters that can be used in MIKE 21 NSW for calibration, the bottom friction was chosen. The increase in the bottom friction coefficient of the near-shore waters is the cause of the higher energy dissipation rate of the waves and vice versa. In this study, the bottom friction coefficient was specified via the Nikuradse roughness parameter.

For calibration purposes, the modelled and measured significant wave height data sets at the bottom mounted wave recorder area point were compared for the period from the 1 to 5 September 2012 with a model time step of $6 \mathrm{~h}$. The model accuracy is assessed by calculating the root mean square error, bias and the correlation coefficient $[7,21]$. These values for various magnitudes of the Nikuradse roughness parameter are presented in the Table 2.

Table 2. The results of the Baltic Sea's near shore wave model calibration.

\begin{tabular}{|c|c|c|c|c|c|c|c|c|c|c|c|}
\hline Nikuradse Roughness Parameter & 0.0005 & 0.001 & 0.002 & 0.003 & 0.004 & 0.005 & 0.006 & 0.007 & 0.008 & 0.009 & 0.010 \\
\hline Root Mean Square Error & 0.272 & 0.270 & 0.266 & 0.266 & 0.236 & 0.261 & 0.261 & 0.260 & 0.259 & 0.258 & 0.257 \\
\hline Bias & 0.119 & 0.116 & 0.113 & 0.113 & 0.110 & 0.108 & 0.105 & 0.105 & 0.103 & 0.102 & 0.099 \\
\hline Correlation Coefficient & 0.705 & 0.702 & 0.705 & 0.704 & 0.705 & 0.705 & 0.701 & 0.700 & 0.700 & 0.700 & 0.700 \\
\hline
\end{tabular}

The bias values indicate that the modelled significant wave heights are higher than the measured ones. Hence, the Nikuradse roughness parameter could be increased further, especially because this enhancement manifests in the constantly decreasing root mean square error and bias values. The decision to finalize the calibration process was reached with reference to the variations of the correlation coefficient values. Figure 2 at least partially explains these variations: it shows the comparison between the measured and modelled significant wave height values.

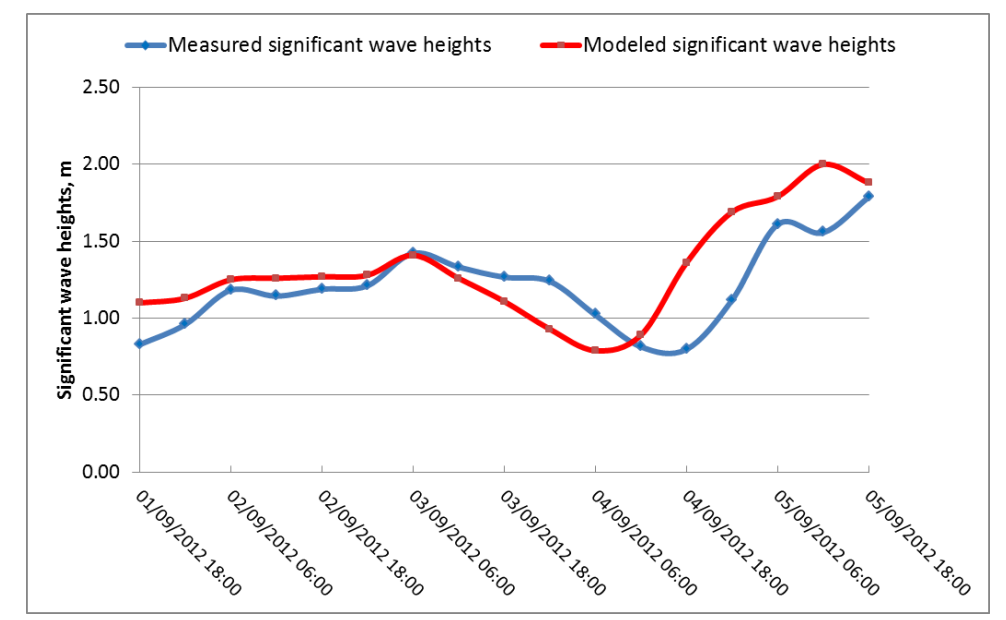

Figure 2. Comparison between measured and modelled significant wave heights in the Baltic Sea near-shore area along the coast of Klaipeda for a Nikuradse roughness parameter value of 0.005.

It is clear from Figure 2. that to obtain lower wave heights, it is not required to increase further the Nikuradse roughness parameter, since the lower wave heights are not necessary in all cases. Furthermore, in Figure 2 there is a visible shift between measured and modelled significant wave heights on 4 January and possible error in measured significant wave heights on 5 January. This is the reason for the variations of the correlation coefficient. Taking into account these factors, a Nikuradse roughness parameter value of 0.005 was selected (also indicated in bold in Table 2) for the further modelling of the dynamics of wave height loss in the Baltic Sea near-shore area. Applying this value to the calibration model runs not only the highest value of the correlation coefficient but also acceptable values of bias and root mean square error was reached. 


\subsection{Spatial Distribution of the Wave Energy Potential}

Average seasonal and annual wave heights for the design years (Table 3) were selected as offshore conditions to model the dynamics of wave height loss. The methodology for the calculation of these wave heights was published in reference [37].

To improve the possibility of assessing the spatial distribution of the wave power potential in the Baltic Sea along the coast of Klaipeda, the wave power of the design waves was estimated alongside the 5, 10, 15, 20, 25 and $30 \mathrm{~m}$ depth isobaths. Alongside these isobaths, calculation points (Figure 1c) were selected, and at each point, the wave power flux of the wave propagating to shore was calculated. Each wave was treated as a separate case, and the stationary mode of the MIKE 21 NSW model was adapted to assess the spatial distribution of the wave power potential along the coast of Klaipeda, taking into account the impacts of depth, wave propagation direction and wind.

Table 3. Average seasonal and annual wave heights for the design years along the coast of Klaipeda.

\begin{tabular}{cccccc}
\hline & \multicolumn{4}{c}{ Average Wave Heights (m) } \\
\cline { 2 - 5 } Characteristic Sea State for the Year & \multicolumn{4}{c}{ Seasonal } \\
& Spring & Summer & Autumn & Winter & \\
\cline { 2 - 5 } & 0.70 & 0.74 & 1.25 & 0.88 & 0.89 \\
High intensity (1973/1974) & 0.56 & 0.55 & 0.72 & 0.85 & 0.67 \\
Median intensity (1994/1995) & 0.57 & 0.48 & 0.56 & 0.52 & 0.53 \\
Low intensity (1976/1977) & \multicolumn{4}{c}{} \\
\hline
\end{tabular}

The wave power flux in this study was estimated using the equation:

$$
P=\rho g \int_{0}^{\infty} S(f) c_{g}(f) d f,
$$

where $\rho$ is the mass density of water (in this case it is brackish water of the Baltic Sea with density $1010 \mathrm{~kg} / \mathrm{m}^{3}$ [74], $g$ is the gravitational constant $\left(9.81 \mathrm{~m} / \mathrm{s}^{2}\right), S(f)$ is the spectral density, and $c_{g}$ is the group velocity. The spectral density was calculated using the JONSWAP wave spectrum modified for the Baltic Sea [75]:

$$
S(f)=K_{m} \frac{H_{s}^{2} \cdot T_{p}}{\left(T_{p} \cdot f\right)^{5}} \exp \left[-\frac{5}{4}\left(\frac{f_{p}}{f}\right)^{4}\right] \gamma^{\beta},
$$

where $K_{m}$ is an empirically determined constant $(0.1786), H_{s}$ is a significant wave height, $T_{p}$ is the peak wave period, $f_{p}$ is the peak frequency, $f$ is the wave frequency, and $\gamma$ is the peak enhancement factor (4.0),

$$
\beta=\exp \left(-\frac{\left(f-f_{p}\right)^{2}}{2 \sigma^{2} f_{p}^{2}}\right),
$$

$\sigma=0.07$ for $f \leq f_{p}, \sigma=0.09$ for $f>f_{p}$, where $\sigma$ is shape parameter.

\section{Results}

\subsection{The Impact of Wave Propagation Direction}

To assess the impact of the wave propagation direction on the wave power potential, three wave propagation directions were selected: west, northwest and southwest. Examples of the change of design heights for the waves propagating to shore from different directions and reaching $5 \mathrm{~m}$ depth are presented in Figure 3. The first observation is that the highest waves reach the shore when they propagate from the west. This is because this direction and the shoreline are almost perpendicular. On the other hand, the considered length of the Lithuanian shore is not parallel to the north direction; therefore, the waves that propagate from the northwest and the southwest lose a different amount 
of energy due to the refraction process. A lesser amount of energy is lost when waves propagate from the southwest. Of course, for the low waves, the difference in wave height loss is only a few centimetres (for example, for a low intensity year's waves, the difference does not exceed $0.02 \mathrm{~m}$ ), a quantity that does not correspond to high wave power losses. However, when higher waves are examined, the impact of wave direction becomes more evident. For example, the highest difference for the autumn average wave height during a high intensity wave year is $0.14 \mathrm{~m}$.

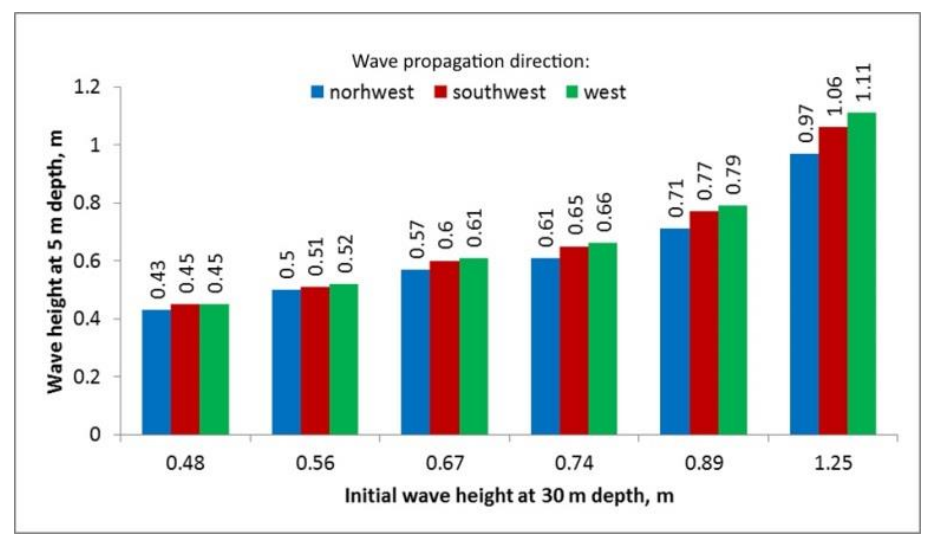

Figure 3. The change in height of waves propagating to the shore.

Another important aspect of the finding that waves lose lesser amount of energy when they are propagating from the southwest than from the northwest becomes clear when these findings are compared with wave rose (Figure 4), created for ERA-Interim grid point (Figure 1b). The fact that not only there are more waves in total that are propagating from the southwest, but also higher amount of higher and more powerful waves propagating from the same direction can influence the selection of the site for wave energy converter installation. For example, the site in question could be the Klaipeda Seaport breakwaters (Figure 1c). There are two breakwaters currently constructed in the Klaipeda Seaport: northern breakwater which is open for waves that are propagating from the north and northwest and southern breakwater which is open for waves that propagate from the south and southwest. Available information from the wave rose suggest that firstly for WEC installation should be considered the southern breakwater. The fact that waves that are propagating from the southwest lose lesser amount of energy is additional great advantage in this case.

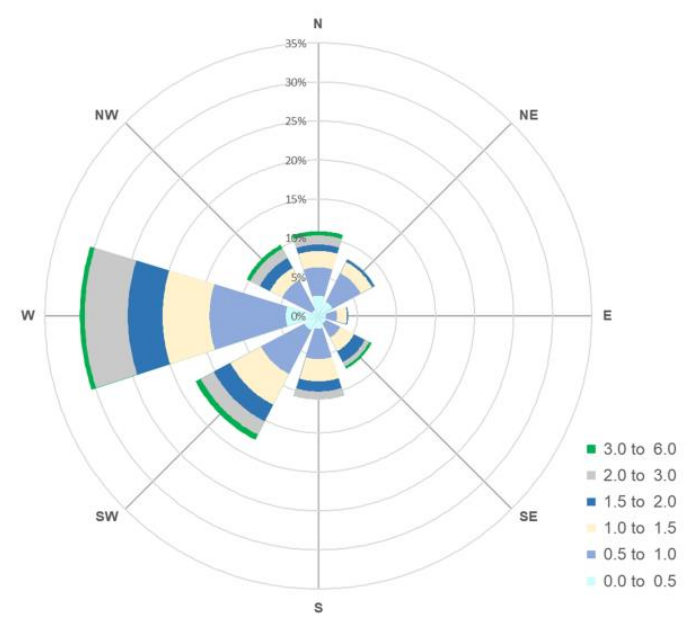

Figure 4. Wave rose for year 2012 (significant wave heights) at ERA-Interim grid point. 
The study clearly revealed that when lower wave power areas are under consideration, the assessment of the wave height loss for greater near-shore depths $(30-50 \mathrm{~m})$ is not that essential. During a low intensity wave year, all waves, with two exceptions (average spring and autumn waves, propagating from southwest), reached a depth of $10 \mathrm{~m}$ without losing any height. Still, this proves the significance of depth for installations of wave energy converters, especially when the areas of lower wave power potential are being studied.

Next, the wave power resources were estimated by summing up the wave power flux values along the isobaths (Figure 1c). It must be emphasized that these resources were calculated by assessing the wave height variations along the isobaths, that is, by summing up the values of the sections at which centre the calculation points were located.

The results showed that wave power resources in the Baltic Sea near-shore area along the coast of Klaipeda decrease starting from $25 \mathrm{~m}$ depth. This is misleading since the isobaths of $25 \mathrm{~m}$ and $30 \mathrm{~m}$ in the model area are shorter in length (Figure 1c). According to the spectral wave energy equations, wave power flux must increase with the increasing depth. Therefore, wave power resources in this study were recalculated to demonstrate the amount of wave power potential per kilometre of isobath, which also corresponds to the averaged wave power fluxes of the design waves at the different depths in the Baltic Sea near-shore area. The recalculations are not shown in detail in this paper. The changes in wave power fluxes of the design waves corresponding to the wave height losses at the $5 \mathrm{~m}$ depth (presented in Figure 3) are shown in Figure 5.

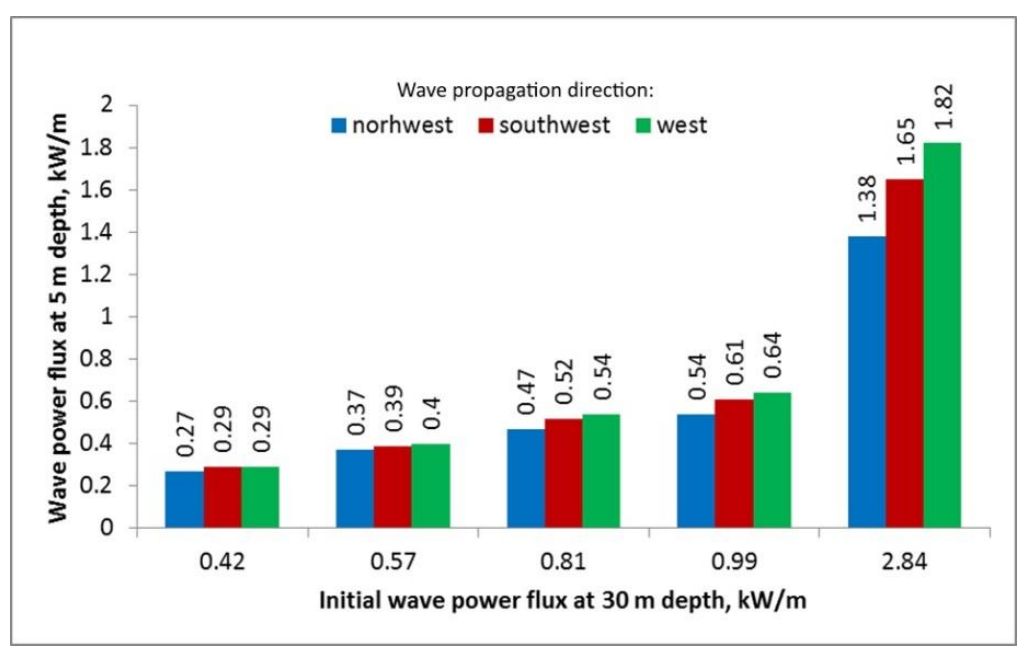

Figure 5. The change in power flux of waves propagating to the shore.

The impact of the wave propagation directions on the Baltic Sea near-shore wave power potential along the coast of Klaipeda is revealed best in Figure 4. When higher waves $(\sim 1.0 \mathrm{~m})$ propagating to shore reach $5 \mathrm{~m}$ depth, they lose approximately $36 \%$ of their power if propagating from the west, $41 \%$ if propagating from the southwest, and even $50 \%$ if propagating from the northwest. Waves of average height $(\sim 0.7 \mathrm{~m})$ lose $35 \%, 38 \%$ and $45 \%$, respectively. Lower waves $(\sim 0.5 \mathrm{~m})$ lose approximately $31 \%$ when propagating from the west and the southwest and $36 \%$ when propagating from the northwest. It is highly likely that due to the refraction process, waves propagating from the north and the south would lose even more of their power.

\subsection{The Impact of Decreasing Depth}

The impact of decreasing depth on the Baltic Sea near-shore wave power potential along the coast of Klaipeda is assessed for the $55^{\circ} 45^{\prime} \mathrm{N}$ parallel starting from $20 \mathrm{~m}$ depth. Along this line, on the basis of modelled wave height loss, the wave power fluxes were calculated. The location of the line, north from of the Klaipeda Seaport, was selected because the territory south of the seaport is the 
Curonian Spit, which is not only a national designated area but also a UNESCO world heritage site. Therefore, the construction of WECs in this near-shore area will be strongly questionable.

To examine the impact of decreasing depth on wave energy resources, three wave heights were selected: the minimum seasonal (low intensity wave year summer average) wave height $(0.48 \mathrm{~m})$, the maximum seasonal (high intensity wave year autumn average) wave height $(1.25 \mathrm{~m})$, and the median intensity wave year annual average wave height $(0.67 \mathrm{~m})$. Into this range falls $69.9 \%$ of the average monthly wave heights from the 1970-2010 period, which were used to determine the distribution of wave heights during the design years. Hence, the obtained curves that describe the impact of the decreasing depth on the wave energy resources in this study reflect the situation during the majority of the year in the Baltic Sea near-shore area along the coast of Klaipeda, when waves propagate from western directions. Figures $6-8$ show the impact of decreasing depth for studied waves that propagate from western directions.

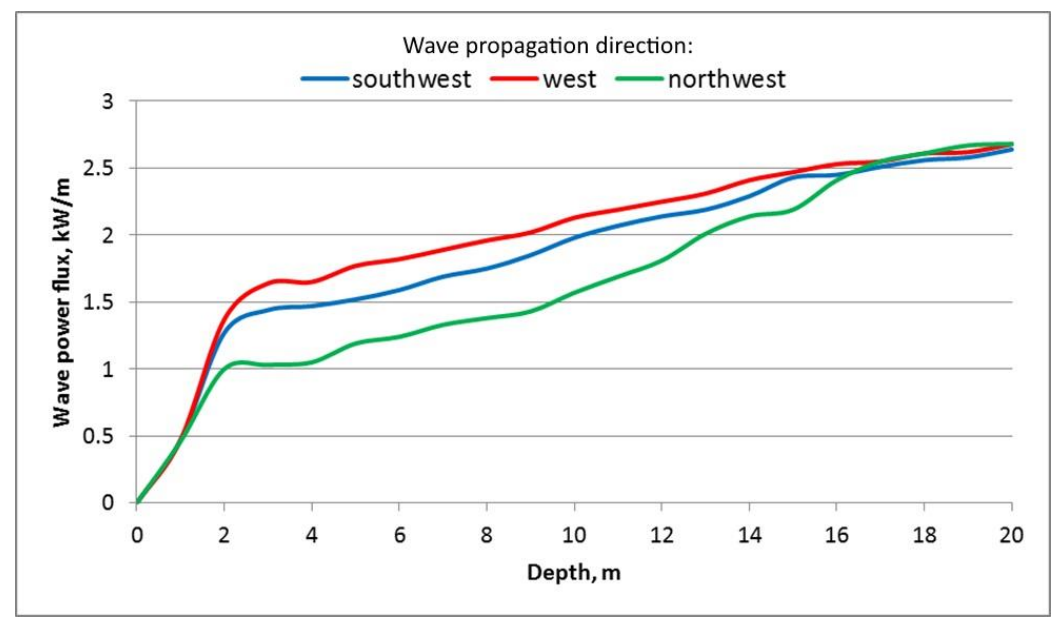

Figure 6. The impact of decreasing depth on wave power flux for a $1.25 \mathrm{~m}$ wave.

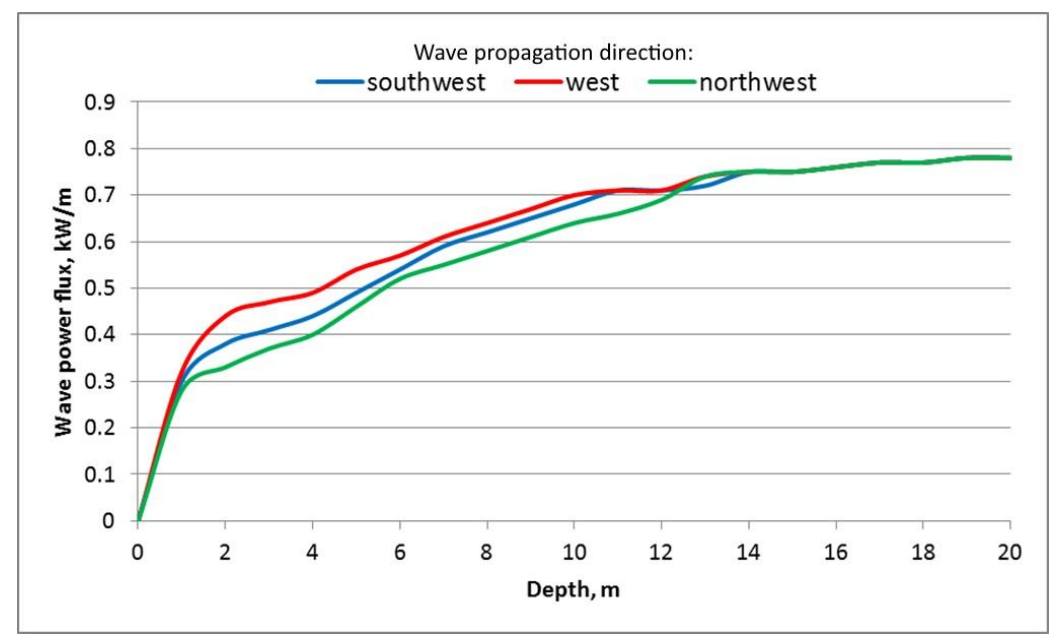

Figure 7. The impact of decreasing depth on wave power flux for a $0.67 \mathrm{~m}$ wave.

From Figures 6 and 7 , it is easy to spot the depth at which a wave starts to get influenced by sea bottom and lose its power due to the decreasing depth. For a $0.67 \mathrm{~m}$ wave, this depth is $14 \mathrm{~m}$, while for $0.48 \mathrm{~m}$ wave, it is $10 \mathrm{~m}$. However, determining this depth for a $1.25 \mathrm{~m}$ wave is still difficult (Figure 8). The amount of wave power that will reach shallower depths depends on both the wave height and the wave propagating direction. 


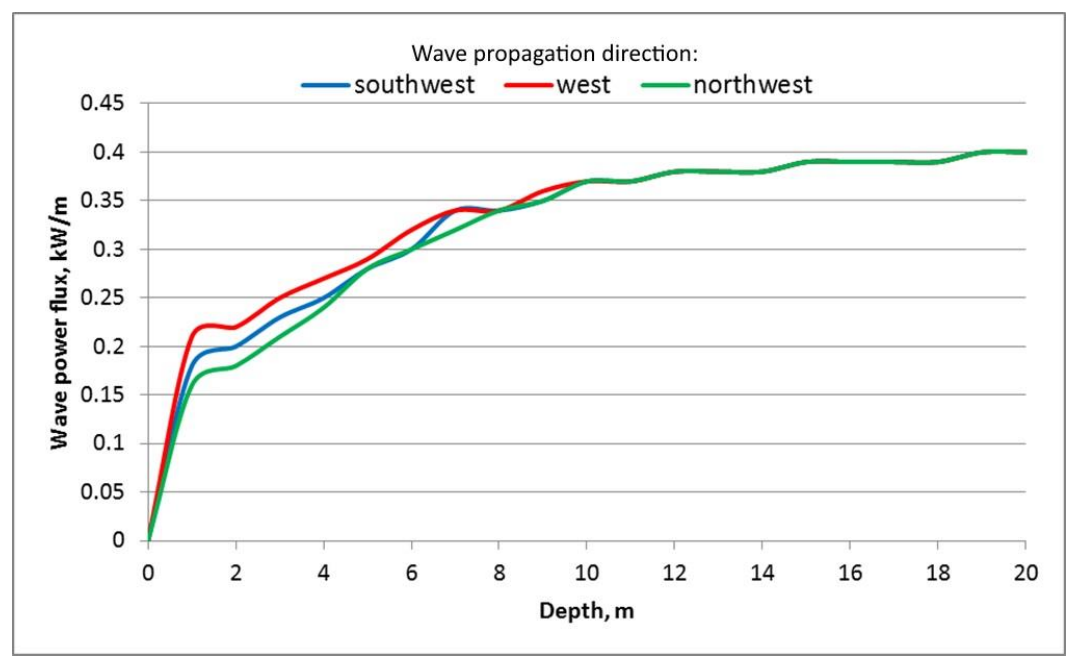

Figure 8. The impact of decreasing depth on wave power flux for a $0.48 \mathrm{~m}$ wave.

The energy losses due to decreasing depth were calculated. These losses are much more substantial compared with the losses due to the propagation direction. If the $1.25 \mathrm{~m}$ wave propagates from the most energetically favourable direction (west) and reaches $5 \mathrm{~m}$ depth, it loses $0.91 \mathrm{~kW} / \mathrm{m}$ or $34.0 \%$ of its power. If the same wave is propagating from the least favourable direction in this case (northwest), it loses an additional $0.58 \mathrm{~kW} / \mathrm{m}$ or $21.6 \%$ of its power. It is a similar story for the $0.67 \mathrm{~m}$ and $0.48 \mathrm{~m}$ waves. The former loses $0.24 \mathrm{~kW} / \mathrm{m}$ or $30.8 \%$ when propagating from the most favourable direction and an additional $0.08 \mathrm{~kW} / \mathrm{m}$ or $10.2 \%$ when propagating from the least favourable direction. The latter loses $0.11 \mathrm{~kW} / \mathrm{m}$ or $27.5 \%$ as well as an additional $0.01 \mathrm{~kW} / \mathrm{m}$ or $2.5 \%$ of its power when propagating from the most favourable and least favourable directions, respectively.

\section{Discussion and Conclusions}

This paper is continuation of the study that was partially published in [37]. This study is different from the usual assessments of near-shore wave power potentials. Not only it is the first spatio-temporal assessment of wave power potential for the Baltic Sea area that in theory has one of the highest wave power potentials, but it is also performed in the area that has almost no instrumental measurements, but where instead long term (over 50 years) visual near-shore wave observations are available. These were used as initial data for the study. Statistical method designed for calculating a distribution of annual hydrological variables using multi-year data was applied together with probability distribution analysis. In such way design waves for high intensity, median intensity and low intensity wave years were calculated and parametrized JONSWAP wave energy spectrum modified for the Baltic Sea was used to estimate wave power flux of design waves. Same design waves were used for assessment of spatial distribution of wave power potential, presented in this paper. From performed extensive literature review it can be stated that the assessment of spatial distribution of wave power potential taking into account wave propagation direction and decreasing depth is still a novelty, especially in low wave energy potential areas.

Since wave power resources depend on fetch, they are distributed unevenly around the globe. The Baltic Sea's wave power resources are low compared to those of oceans yet are similar to those of other semi-enclosed seas, such as the Black Sea or the Persian Gulf. Nevertheless, the amount of published studies on the wave power potential in the Baltic Sea is constantly growing. It is already known, that the average wave power flux in the Baltic Sea can reach 4-5 kW/m [64]. In the coastal "hot spots" areas average wave power flux can reach $2.55 \mathrm{~kW} / \mathrm{m}$ at non-sheltered condition such as island of Saaremaa [66] and approximately $1.6 \mathrm{~kW} / \mathrm{m}$ in sheltered conditions such as Bay of Gdansk [76]. In the Lithuanian coast of the Baltic Sea the average wave power flux can reach $1-2 \mathrm{~kW} / \mathrm{m}[37,66]$, 
therefore it can be further assessed as possible location for electricity generation from waves. This study represents a first attempt to conduct a study of spatial distribution of the near-shore wave power resources in the southeastern region of the Baltic Sea, taking into account wave propagation direction and decreasing depth.

The assessment of the impact of the wave propagation direction on wave power resources in the Baltic Sea near-shore area along the coast of Klaipeda revealed that the most powerful waves reach the Lithuanian coast when they propagate from the west. The most powerful in this case means that these waves loses the least of their power while propagating to the shore.

When lower waves $(\sim 0.5 \mathrm{~m})$ are propagating to the shore from the west starting from $30 \mathrm{~m}$ and reaching $5 \mathrm{~m}$ depth they lose approximately $31 \%$ of their power flux. Change of propagation direction decreases the wave height of approximately $0.02 \mathrm{~m}$ and increases the losses just to $36 \%$.

When higher waves (e.g., $1.25 \mathrm{~m}$ ) are studied, their initial percentage loss of power flux due to the decreasing depth is similar-34.0\%, however the change of propagation direction can increase the loses to $50 \%$ or more. Of course, the numerical value of this power loss is significantly higher than for lower waves.

Still, typical waves in the Baltic Sea near-shore area along the coast of Klaipeda are low, and therefore, they begin to be impacted by decreasing depth and lose their power at relatively low (10-14 m) depths. However, to turn this into an advantage and to avoid a rapid decrease in wave power flux due to the decreasing depth, the wave power converter would have to work efficiently under low power conditions. Having similar spatial distribution of the design waves' power fluxes in various depths and the calculations of their power flux losses due to the propagation to the shore can help to assess the most economically feasible site for the wave power converter.

Acknowledgments: Authors would like to acknowledge the Lithuanian EPA Department of Marine Research for providing Klaipėda coastal hydrometeorological station data.

Author Contributions: Egidijus Kasiulis design the research and wrote the paper under supervision of Jens Peter Kofoed. Arvydas Povilaitis and Algirdas Radzevičius were consultants and helped to prepare a final version of the manuscript.

Conflicts of Interest: Authors declare no conflict of interest.

\section{References}

1. International Energy Agency-Ocean Energy Systems (IEA-OES). Annual Report 2013. Implementing Agreement on Ocean Energy Systems; The Executive Committee of Ocean Energy Systems: Lisboa, Portugal, 2014.

2. World Energy Council. 2010 Survey of Energy Resources; World Energy Council: London, UK, 2010; pp. 562-587, ISBN 978-0-946121-021.

3. Kinsman, B. Wind Waves: Their Generation and Propagation on the Ocean Surface; Prentice-Hall: Englewood Cliffs, NJ, USA, 1965; ISBN 978-0-486-64652-7.

4. Mørk, G.; Barstow, S.; Kabuth, A.; Pontes, M.T. Assessing the global wave energy potential. In Proceedings of the 29th International Conference on Ocean, Offshore and Arctic Engineering, Shanghai, China, 6-11 June 2010.

5. Gunn, K.; Stock-Williams, C. Quantifying the global wave power resource. Renew. Energy 2012, 44, $296-304$. [CrossRef]

6. Reguero, B.G.; Losada, I.J.; Méndez, F.J. A global wave power resource and its seasonal, interannual and long-term variability. Appl. Energy 2015, 148, 366-380. [CrossRef]

7. García-Medina, G.; Özkan-Haller, H.T.; Ruggiero, P. Wave resource assessment in Oregon and Southwest Washington, USA. Renew. Energy 2014, 64, 203-314. [CrossRef]

8. Pastor, S.; Liu, Y. Wave climate resource analysis based on a revised gamma spectrum for wave energy conversion technology. Sustainability 2016, 8, 1321. [CrossRef]

9. Lenee-Bluhm, P.; Paasch, R.; Özkan-Haller, H.T. Characterizing the wave energy resource of the US Pacific Northwest. Renew. Energy 2011, 36, 2106-2119. [CrossRef]

10. Marine Energy_Wave, Tidal and Other Water Current Converters-Part 101: Wave Energy Resource Assessment and Characterization; IEC 62600-101 TS Ed. 1; International Electrotechnical Commision: Geneva, Switzerland, 2012. 
11. Reikard, G.; Pinson, P.; Bidlot, J. Forecasting ocean wave energy: The ECMWF wave model and time series methods. Ocean Eng. 2011, 38, 1089-1099. [CrossRef]

12. Dunnett, D.; Wallace, J.S. Electricity generation from wave power in Canada. Renew. Energy 2009, 34, $179-195$. [CrossRef]

13. Ortega, S.; Osorio, A.F.; Agudelo, P. Estimation of the wave power resource in the Caribbean Sea in areas with scarce instrumentation. Case study: Isla Fuerte, Colombia. Renew. Energy 2013, 57, 240-248. [CrossRef]

14. Guiberteau, K.L.; Liu, Y.; Lee, J.; Kozman, T.E. Investigation of developing wave energy technology in the Gulf of Mexico. Distrib. Gener. Altern. Energy 2012, 27, 36-52. [CrossRef]

15. Alonso, R.; Solari, S.; Teixeira, L. Wave energy resource assessment in Uruguay. Energy 2015, 93, $683-696$. [CrossRef]

16. Contestabile, P.; Ferrante, V.; Vicinanza, D. Wave energy resource along the coast of Santa Catarina (Brazil). Energies 2015, 8, 14219-14243. [CrossRef]

17. Aoun, N.S.; Harajli, H.A.; Queffeulou, P. Preliminary appraisal of wave power prospects in Lebanon. Renew. Energy 2013, 53, 165-173. [CrossRef]

18. Alamian, R.; Shafaghat, R.; Miri, S.J.; Yazdanshenas, N.; Shakeri, M. Evaluation of technologies for harvesting wave energy in Caspian Sea. Renew. Sustain. Energy Rev. 2014, 32, 468-476. [CrossRef]

19. Hadadpour, S.; Etemad-Shahidi, A.; Jabbari, E.; Kamranzad, B. Wave energy and hot spots in Anzali port. Energy 2014, 74, 529-536. [CrossRef]

20. Kamranzad, B.; Etemad-Shahidi, A.; Chegini, V. Assessment of wave energy variation in the Persian Gulf. Ocean Eng. 2013, 70, 72-80. [CrossRef]

21. Zheng, C.; Pan, J.; Li, J. Assessing the China Sea wind energy and wave energy resources from 1988 to 2009. Ocean Eng. 2013, 65, 39-48. [CrossRef]

22. Liang, B.; Fan, F.; Yin, Z.; Shi, H.; Lee, D. Numerical modelling of the nearshore wave energy resources of Shandong Peninsula, China. Renew. Energy 2013, 57, 330-338. [CrossRef]

23. Wang, S.; Yuan, P.; Li, D.; Jiao, Y. An overview of ocean renewable energy in China. Renew. Sustain. Energy Rev. 2011, 15, 91-111. [CrossRef]

24. Zhang, D.; Li, W.; Lin, Y. Wave energy in China: Current status and perspectives. Renew. Energy 2009, 34 , 2089-2092. [CrossRef]

25. Kim, G.; Lee, M.E.; Lee, K.S.; Park, J.; Jeong, W.M.; Kang, S.K.; Soh, J.G.; Kim, H. An overview of ocean renewable energy resources in Korea. Renew. Sustain. Energy Rev. 2012, 16, 2278-2288. [CrossRef]

26. Mirzaei, A.; Tangang, F.; Juneng, L. Wave energy potential along the east coast of Peninsular Malaysia. Energy 2014, 68, 722-734. [CrossRef]

27. Chiu, F.; Huang, W.; Tiao, W. The spatial and temporal characteristics of the wave energy resources around Taiwan. Renew. Energy 2013, 52, 218-221. [CrossRef]

28. Sanil Kumar, V.; Anoop, T.R. Wave energy resource assessment for the Indian shelf seas. Renew. Energy 2015, 76, 212-219. [CrossRef]

29. Morim, J.; Cartwright, N.; Etemad-Shahidi, A.; Strauss, D.; Hemer, M. A review of wave energy estimates for nearshore shelf waters off Australia. Int. J. Mar. Energy 2014, 7, 57-70. [CrossRef]

30. Hughes, M.G.; Heap, A.D. National-scale wave energy resource assessment for Australia. Renew. Energy 2010, 35, 1783-1791. [CrossRef]

31. Behrens, S.; Hayward, J.; Hemer, M.; Osman, P. Assessing the wave energy converter potential for Australian coastal regions. Renew. Energy 2012, 43, 210-217. [CrossRef]

32. Kelly, G. History and potential of renewable energy development in New Zealand. Renew. Sustain. Energy Rev. 2011, 15, 2501-2509. [CrossRef]

33. Joubert, J.R.; van Niekerk, J.L. South African Wave Energy Resource Data; Centre for Renewable and Sustainable Energy Studies: Matieland, South Africa, 2013.

34. International Energy Agency-Ocean Energy Systems (IEA-OES). Annual Report 2014. Implementing Agreement on Ocean Energy Systems; The Executive Committee of Ocean Energy Systems: Lisboa, Portugal, 2015.

35. Hammar, L.; Ehnberg, J.; Mavume, A.; Cuamba, B.C.; Molander, S. Renewable ocean energy in the Western Indian Ocean. Renew. Sustain. Energy Rev. 2012, 16, 4938-4950. [CrossRef]

36. World Bank. The Welfare Impact of Rural Electrification: A Reassessment of the Costs and Benefits; World Bank Independent Evaluation Group: Washington, DC, USA, 2008. 
37. Kasiulis, E.; Punys, P.; Kofoed, J.P. Assessment of theoretical near-shore wave power potential along the Lithuanian coast of the Baltic Sea. Renew. Sustain. Energy Rev. 2015, 41, 134-142. [CrossRef]

38. Gleizon, P.; Campuzano, F.J.; Garcia, P.C.; Gomez, B.; Martinez, A. Wave energy mapping along the European Atlantic coast. In Proceedings of the 11th European Wave and Tidal Energy Conference, Nantes, France, 6-11 September 2015.

39. Sierra, J.P.; Mosso, C.; Mestres, M.; Gonzales-Marco, D.; Grino, M. Assessment of the wave energy resource around the Ria de Vigo (NW Spain). In Proceedings of the 11th European Wave and Tidal Energy Conference, Nantes, France, 6-11 September 2015.

40. Silva, D.; Bento, A.R.; Martinho, P.; Guedes Soares, C. High resolution local wave energy modelling in the Iberian Peninsula. Energy 2015, 91, 1099-1112. [CrossRef]

41. Guillou, N. Evaluation of wave energy potential in the Sea of Iroise with two spectral models. Ocean Eng. 2015, 106, 141-151. [CrossRef]

42. Rute Bento, A.; Martinho, P.; Guedes Soares, C. Numerical modelling of the wave energy in Galway Bay. Renew. Energy 2015, 78, 457-466. [CrossRef]

43. Gallagher, S.; Tiron, R.; Whelan, E.; Gleeson, E.; Dias, F.; McGrath, R. The nearshore wind and wave energy potential of Ireland: A high resolution assessment of availability and accessibility. Renew. Energy 2016, 88, 494-516. [CrossRef]

44. Marquis, L.; Kramer, M.M.; Kringelum, J.F.; Chozas, J.F.; Helstrup, N.E. Introduction of Wavestar wave energy converter at the Danish offshore wind power plant Horns Rev 2. In Proceedings of the 4th International Conference on Ocean Energy, Dublin, Ireland, 17-19 October 2012.

45. Besio, G.; Mentaschi, L.; Mazzino, A. Wave energy resource assessment in the Mediterranean Sea on the basis of a 35-year hindcast. Energy 2016, 94, 50-63. [CrossRef]

46. Emmanouil, G.; Galanis, G.; Kalogeri, C.; Zodiatis, G.; Kallos, G. 10-year high resolution study of wind, sea waves and wave energy assessment in the Greek offshore areas. Renew. Energy 2016, 90, 399-419. [CrossRef]

47. Ponce de León, S.; Orfila, A.; Simarro, G. Wave energy in the Balearic Sea. Evolution from a 29 year spectral wave hindcast. Renew. Energy 2016, 85, 1192-1200. [CrossRef]

48. Jadidoleslam, N.; Özger, M.; Ağıralioğlu, N. Wave power potential assessment of Aegean Sea with an integrated 15-year data. Renew. Energy 2016, 86, 1045-1059. [CrossRef]

49. Beatty, S.J.; Wild, P.; Buckham, B.J. Integration of a wave energy converter into the electricity supply of a remote Alaskan island. Renew. Energy 2010, 35, 1203-1213. [CrossRef]

50. Stopa, J.E.; Filipot, J.; Li, N.; Cheung, K.F.; Chen, Y.; Vega, L. Wave energy resources along the Hawaiian Island chain. Renew. Energy 2013, 55, 305-321. [CrossRef]

51. OWC Pico Power Plant. Available online: http:/ / www.pico-owc.net/ (accessed on 6 November 2017).

52. Rusu, L.; Guedes Soares, C. Wave energy assessments in the Azores islands. Renew. Energy 2012, 45, 183-196. [CrossRef]

53. Iglesias, G.; Carballo, R. Wave power for La Isla Bonita. Energy 2010, 35, 5013-5021. [CrossRef]

54. Gonçalves, M.; Martinho, P.; Guedes Soares, C. Assessment of wave energy in the Canary Islands. Renew. Energy 2014, 68, 774-784. [CrossRef]

55. Veigas, M.; Ramos, V.; Iglesias, G. A wave farm for an island: Detailed effects on the nearshore wave climate. Energy 2014, 69, 801-812. [CrossRef]

56. Ram, K.; Narayan, S.; Ahmed, M.R.; Nakavulevu, P.; Lee, Y. In situ near-shore wave resource assessment in the Fiji Islands. Energy Sustain. Dev. 2014, 23, 170-178. [CrossRef]

57. Rusu, E.; Onea, F. Estimation of the wave energy conversion efficiency in the Atlantic Ocean close to the European islands. Renew. Energy 2016, 85, 687-703. [CrossRef]

58. Legal Sources on Renewable Energy. Available online: http://www.res-legal.eu/search-by-country/iceland/ (accessed on 6 November 2017).

59. Vicinanza, D.; Contestabile, P.; Ferrante, V. Wave energy potential in the north-west of Sardinia (Italy). Renew. Energy 2013, 50, 506-521. [CrossRef]

60. Monteforte, M.; Lo Re, C.; Ferreri, G.B. Wave energy assessment in Sicily (Italy). Renew. Energy 2015, 78, 276-287. [CrossRef] 
61. Strömstedt, E.; Savin, A.; Heino, H.; Antbrams, K.; Haikonen, K.; Götschl, T. Project WESA (Wave Energy for a Sustainable Archipelago)—A single heaving buoy wave energy converter operating and surviving ice interaction in the Baltic Sea. In Proceedings of the 10h European Wave and Tidal Energy Conference, Aalborg, Denmark, 2-5 September 2013.

62. Akpınar, A.; Kömürcü, M.İ. Wave energy potential along the south-east coasts of the Black Sea. Energy 2012, 42, 289-302. [CrossRef]

63. Falnes, J. Research and development in ocean-wave energy in Norway. In Proceedings of the International Symposium on Ocean Energy Development, Hokkaido, Japan, 26-27 August 1993.

64. Iglesias, G.; Carballo, R. Offshore and inshore wave energy assessment: Asturias (N Spain). Energy 2010, 35 , 1964-1972. [CrossRef]

65. Henfridsson, U.; Neimane, V.; Strand, K.; Kapper, R.; Bernhoff, H.; Danielsson, O.; Leijon, M.; Sundberg, J.; Thorburn, K.; Ericsson, E.; et al. Wave energy potential in the Baltic Sea and the Danish part of the North Sea, with reflections on the Skagerrak. Renew. Energy 2007, 32, 2069-2084. [CrossRef]

66. Soomere, T.; Eelsalu, M. On the wave energy potential along the eastern Baltic Sea coast. Renew. Energy 2014, 71, 221-233. [CrossRef]

67. Johnson, H.K. On modelling wind-waves in shallow and fetch limited areas using the method of Holthuijsen, Booij and Herbers. J. Coast. Res. 1998, 14, 917-932.

68. Dingemans, M.W. Verification of Numerical Wave Equation Models with Field Measurements, CREDITZ Verification Haringuliet; Rep. No. W488; Delft Hydraulic Lab: Delft, The Netherlands, 1983.

69. Jonsson, I.G. Wave boundary layers and friction factors. In Proceedings of the 10th International Conference on Coastal Engineering, Tokyo, Japan, 13-18 September 1966.

70. Nielsen, P. Some Basic Concepts of Wave Sediment Transport; Serie Paper No. 20; Institute of Hydrodinamics and Hydraulic Engineering, Technical University of Denmark: Lyngby, Denmark, 1979.

71. Battjes, J.A.; Janssen, J.P.F.M. Energy loss and set-up due to breaking of random waves. In Proceedings of the 16th International Conference on Coastal Engineering, Hamburg, Germany, 27 August-3 September 1978.

72. Aanderaa Data Instruments. SeaGuard Platform. Available online: http://www.aanderaa.com/ productsdetail.php?SeaGuard-Platform-25 (accessed on 6 November 2017).

73. European Centre for Medium-Range Weather Forecasts. Available online: http://www.ecmwf.int (accessed on 4 December 2017).

74. Lepparanta, M.; Myrberg, K. Physical Oceanography of the Baltic Sea; Springer: Chichester, UK, 2009; ISBN 978-3-540-79703-6.

75. Feistel, R.; Nausch, G.; Wasmund, N. State and Evolution of the Baltic Sea, 1952-2005. A Detailed 50-Year Survey of Meteorology and Climate, Physics, Chemistry, Biology, and Marine Environment; John Wiley \& Sons: Hoboken, NJ, USA, 2008; ISBN 978-0-471-97968-5.

76. Kovaleva, O.; Eelsalu, M.; Soomere, T. Hot spots of large wave energy resources in relatively sheltered sections of the Batic Sea coast. Renew. Sustain. Energy Rev. 2017, 74, 424-437. [CrossRef]

(C) 2017 by the authors. Licensee MDPI, Basel, Switzerland. This article is an open access article distributed under the terms and conditions of the Creative Commons Attribution (CC BY) license (http://creativecommons.org/licenses/by/4.0/). 